\title{
Rethinking the Ornament with/in Luigi Nono's Late Electroacoustic Works
}

\author{
Repensar o ornamento com/em obras eletroacústicas tardias de Luigi Nono
}

Kevin Gohon

Université Rennes 2, France

\begin{abstract}
This paper aims at examining the manifestations of the ornamental phenomenon in the musical project that Luigi Nono developed in the last ten years of his life. Indeed, despite the fact that the musical language of his late style seems to be in contradiction with the presence of any kind of ornamentation -whether because of his inheritance from the Viennese modernism or his rejection to any kind of figurative musical discourse -, certain features of Nono's late style echo in some way an ornamental logic, as it is set as a general aesthetic category since the 18th century. Therefore, this paper demonstrates that the first manifestation of the "mobile sound" is related to a shifting of the traditional techniques of ornamentation, and then tries to enlighten the expression of the musical discourse in the late spatialized works from the perspective of an ornamental logic.
\end{abstract}

Keywords: Luigi Nono; Electroacoustic Music; Ornamental Aesthetic; Das atmende Klarsein; Risonanze erranti

Resumo: O objetivo deste artigo é examinar as manifestações do fenômeno ornamental no projeto musical que Luigi Nono desenvolveu nos últimos dez anos de sua vida. De fato, apesar da linguagem musical de seu estilo tardio parecer estar em contradição com a presença de qualquer tipo de ornamentação - seja por sua herança do modernismo vienense ou pela sua rejeição por qualquer tipo de discurso musical figurativo -, certas características do estilo tardio de Nono ecoam como uma lógica ornamental, já que é definida como uma categoria estética geral desde o século XVIII. Portanto, este trabalho demonstra que a primeira manifestação do "som móvel" está relacionada a um deslocamento das técnicas tradicionais de ornamentação e, em seguida, tenta iluminar a expressão do discurso musical nos trabalhos espaciais tardios a partir da perspectiva de uma lógica ornamental.

Palavras-chave: Luigi Nono; Música Eletroacústica; Estética Ornamental; Das atmende Klarsein; Risonanze erranti 
MUSICA THEORICA Revista da Associação Brasileira de Teoria e Análise Musical 2019, v. 4, n. 1, p. 160-187-Journal of the Brazilian Society for Music Theory and Analysis@ TeMA 2019 - ISSN 2525-5541

\section{Introduction}

In a long talk with Massimo Cacciari and Michele Bertaggia, presented in the program notes of the performance of Prometeo in Paris in 1987, Luigi Nono explained his interest in infinite listening possibilities and exposed that

[...] the composition of a music that wants today to restore the infinite possibilities of listening by using a "non-geometrisable" space also faces the dissolution of the normal time, the time of narration and visualization... (Bertaggia 1987, p. 138). ${ }^{1}$

The fundamental rejection of the logic of discourse and the "imaged" acceptance of the musical tone, notably reaffirmed in an interview given to Philippe Albèra, ${ }^{2}$ seems to exclude de facto madrigalism, and rhetorical embellishment, which is the main criteria of the ornamental principle. In this respect, the Venetian composer's approach fits with his inheritance of the Viennese modernism, reaffirming at the same time his attachment to Schoenberg's music. Indeed, even if Schoenberg demonstrates that embellishments are not minor additions to Baroque music in "About ornaments, primitive rhythms, etc., and bird song" (1922), Schoenberg has expressed the same stance as Adolf Loos did in his Ornament and Crime, as he considers the ornamental figure obsolete since homophonic writing became predominant in the development of Western music.

However, the ornamental phenomenon cannot be reduced to ornamentation, as evidenced by the numerous studies of and attempts to define the ornament in art and philosophy. ${ }^{3}$ It is even set as an independent aesthetic category since the 18th century - at least - as its progressive diversification has revealed a complex relationship between the background and the surface, the material and its ornamentation, which cannot be restricted to the hierarchy

\footnotetext{
1 “De manière plus générale, la composition d'une musique qui veuille aujourd'hui restituer des possibilités d'écoute infinies, en usant d'un espace non géométrisable, se heurte aussi à la dissolution du temps normal, du temps de la narration et de la visualisation..."

2 "The logic of discourse is something terrifying to me. The taste of formulation, of the formula, causes in me an almost physical reaction" (Albèra 1987, p. 20). "La logique du discours est pour moi quelque chose de terrifiant. Le goût de la formulation, de la formule, provoque chez moi une réaction presque physique."

${ }^{3}$ For example, see Golsenne 2012, Carboni 2012, Golsenne, A. et al. 2010, Buci-Glucksmann 2008, Dewitte 2010, Dewitte 2005, Saint Girons 2005 or Bettini 2016.
} 
imposed by its initial decorative function. Thereupon, the ornament induces an "ornamental mode" defined by a "manner of expressing, which reduces or completely eliminates the referential dimension of the arts. The created thing [...] is not an end in itself but leads to the transfiguration of the one that it affects" (Grabar 1996, p. 186; Buci-Glucksmann 2008, p. 90). Hence, the involvement of the ornamental phenomenon in Nono's late works can be reassessed.

In this perspective, this paper will try to demonstrate that the sound and space concepts that Luigi Nono developed in his late electroacoustic works employ a particular setting of the ornamental phenomenon in order to "restore the infinite possibilities of listening". An analysis of Das atmende Klarsein will show that Nono unfolds the traditional ornamental principles between a pitchbased and a sound-based writing and echoes the methods of variation defined by Schoenberg in order to increase the complexity of the sound and the structure of the work. Then, an analysis of Risonanze erranti based on the writing processes highlighted in Das atmende Klarsein will expose that the renewal of the musical discourse operated by the composer follows a specific logical pattern that one can describe as ornamental and deeply affects the expression of the musical work.

\section{Luigi Nono and the "Venetian reality", from a rhetorical to an ontological approach to the ornament}

As mentioned in the introduction of this paper, the modes of presentation and writing developed during Viennese modernism, in music, architecture and visual arts, cannot fit with the concept of embellishment. In "About ornaments, primitive rhythms, etc., and bird song" (1922), Schoenberg offers a detailed study of the problem of ornamentation in early twentieth-century music. The first part of the text reminds that the exclusion of ornamental practices during the second half of the nineteenth century, yet established as one of the main expressive means in occidental musical writing since the Baroque era at least, relies both on a criterion of intelligibility and the evolution of the audiences. Indeed, in a cultural context largely influenced by the ideas of the French Revolution, the fact that art should be accessible to everyone required to open and enlarge the places of performance in order to reach a larger number of listeners. On another hand, it became necessary to level the complexity of its languages so that it could be understood by everyone, including those who had been deprived of artistic erudition until then. Consequently, according to the composer, "style became 
MUSICA THEORICA Revista da Associação Brasileira de Teoria e Análise Musical 2019, v. 4, n. 1, p. 160-187-Journal of the Brazilian Society for Music Theory and Analysis@ TeMA 2019 - ISSN 2525-5541

broader; repetitions (sequences) regained the upper hand; quicker notes (fluidity) dropped out as far as possible; one limited oneself to main points; wherever possible, ornaments were regarded as minor points and so mostly left out" (Schoenberg 2010, p. 298).

Nevertheless, the so-called secondary value of embellishment appears to him as a misunderstanding and the argument of eviction unconvincing. The latter would be influenced by the hierarchy imposed on principal notes and embellishment figures, which are represented by non-integrated signs in the musical symbolic system, "in a way which soon nobody understood any more, since it was passed on purely by word of mouth" ${ }^{4}$ (Schoenberg 2010, p. 199). As the composer explains, ornaments are not as loose as the austerity of the information contained in the score implies, precisely because of the polyphonic nature of writing. While "the expression of the idea, its marking-off and workingout, happened so precisely and exactly within the notes written down" (Schoenberg 2010, p. 303), the continuo realized by the performer was certainly secondary, in relation to the content of the work, but it was not less obliged than a fully prescribed accompaniment: its function is precisely an adornment of the structure which closely follows its evolution. For Schoenberg, the Baroque practice of ornamentation is less the result of a freedom of expression acquired to the performing musician than a variable of adjustment of the sound mass allowing to adapt the discourse to the instruments available at the time of performance.

However, it is because the ornament is not a negligible decoration in the context of the traditional polyphonic style that the modern composer must oppose its preservation. As Schoenberg develops in a short text entitled "Ornaments and construction", which complements the previous article, the homophonic style of the new music requires the abandonment of the melodicharmonic adornment inherited from the contrapuntal and polyphonic aesthetics. The musical discourse no longer resides in the realization of a "sketch" which needs embellishment to be expressive, but it arises from the thematic development derived from a fundamental motive. In this particular kind of composition, "there will have to be a rather slower rate of succession among the

\footnotetext{
4 Schoenberg contradicts this thesis following a summary observation of the stylistic characteristics of Johann Sebastian Bach and his contemporaries.
} 
notes, even for reasons of comprehensibility" (Schoenberg 2010, p. 312), so as not to interfere both with the exposure of the material and the logical deduction process. In this perspective, Schoenberg reinvests a fundamental stance of Modernity defended by Adolf Loss in Ornament and crime (1908).

Indeed, the architect considers that the embellishment - which he compares to an "epidemic" (Loos 2003, p. 63) - cannot be suitable for modern man according to its supererogatory nature, because it implies a vain expense of work, money and material. The aesthetics of utility defended in this text submits the form exclusively to the expression of the function so as to prevent it from the exhaustion of taste, estimated faster than that of the useful features of the tool. As Loss writes,

the modern man who sacralises the ornament as a sign of artistic overfull of past eras will immediately recognize the tortured, laborious and sickly aspect of modern ornaments. Ornament can no longer be created by somebody living at our cultural stage (Loos 2003, p. 69).

Despite the fact that Ornament and Crime constitutes the manifesto of the most widespread idea of modernity in Western music during the twentieth century, it depicts the culmination of a long series of criticisms and essays specifically aimed against Gustav Klimt, who actually represents a different kind of modernity through the Art nouveau, as noticed by Christine Buci-Glucksman (see Buci-Glucksmann 2008, p. 36). Moreover, one can find many aesthetic approaches of an "ornamental modernism" across the century, notably thought by Wilhelm Worringer, Hans Georg Gadamer, Jacques Derrida or Gilles Deleuze.

According to Gadamer, the relationship between the ornament and the object it embellishes necessarily falls under the authority of a criterion of coherence which fits the latter's form to the space where evolves the embellishment:

[...] the ornament is precisely not primarily a thing that is sufficient for itself and then added to another, but it is part of the way in which what its supports is represented. One can also say of the ornament that it is part of the representation; however, representation (Darstellung) is an ontological process, it is a representation (Repräsentation) (Gadamer 2018, p. 262). ${ }^{5}$

\footnotetext{
5 “[...] l'ornement n'est précisément pas d'abord une chose qui se suffit à elle-même et qu'on ajoute ensuite à une autre, mais il fait partie de la manière dont ce qui le porte se représente. C'est à juste
} 
MUSICA THEORICA Revista da Associação Brasileira de Teoria e Análise Musical 2019, v. 4, n. 1, p. 160-187-Journal of the Brazilian Society for Music Theory

This observation is not only valid for ornamentation in its sensitive manifestation; it also creates an aesthetic criterion corresponding to any art "that gives a configuration to space" (Gadamer 2018, p. 259), according to the model of architecture. We can then consider that it applies to music, due to the fact that the sound phenomenon is closely dependent on the spatial context in which it emerges. As Gadamer writes,

it is not a question of finding, in addition and outside, a place for a work in itself completed; on the contrary, it is necessary to submit to the power, which is that of the work itself, to structure space. The work must thus adapt to the given, just as it lays down its own conditions (Gadamer 2018, p. 260). ${ }^{6}$

For comparison, Gadamer's ontological principle of "decoration" can be illustrated with Nono's particular approach to spatialization, as his music no longer confronts the neutralized spaces enumerated by the philosopher (the model of theater or concert hall) but calls to be performed in any resonant space by harmonizing with the space itself while the musical discourse characterizes it acoustically.

If the idea of an ontological ornamental perspective of music is akin to a theoretical metaphor whose scope is limited here to the description of the singular relationship that is being made between all sound production and the environment in which it spreads, it introduces however two essential postulates for the attempt to identify a renewal of the ornamental dimension in electroacoustic music. In the first place, the ornament appears as a category of thought which, although still related to the concept of decoration, is not confined to its figurative property, nor to the supererogatory nature that Adolf Loos denounced. However, this approach of the ornament "which diverts from the task of ornamentation" (Dewitte 2005, p. 41), which departs from its representative essence, seems to echo the principle of variation in Western music:

titre qu'on peut dire aussi de l'ornement qu'il fait partie de la représentation; or, la représentation (Darstellung) est un processus ontologique, elle est représentation (Repräsentation)."

6 " [...] il ne s'agit pas de trouver, en plus et du dehors, place à une œuvre en elle-même achevée; il faut au contraire se soumettre à la puissance, qui est celle de l'œuvre même, de structurer l'espace. L'œuvre doit ainsi s'adapter au donné, tout comme elle pose ses propres conditions $[\ldots] . "$ 
it does not act on a secondary level in the formation of shape but influences the development, and even dictates the structure at times. ${ }^{7}$

Secondly, Nono's electroacoustic music maintains a particular affinity with a thought of the ornamental phenomenon of which Venice can be considered as the quintessential representation. The fact that the composer has emphatically claimed the musical, pictorial, architectural and historical heritage of his hometown during the 1980s is not trivial. As Laurent Feneyrou points out, the singular approach to the origin of Prometeo, and the formulation of the mixed musical perspectives accompanying it, "rest on the rereading of Venice" (Feneyrou 1993, p. 16). When Enzo Restagno questions him about the source of what he considers to be an "unveiling of the Venetian reality", Nono answers:

First of all, I have to tell you that this unveiling is still going on today. I would say to you that it seems to me that I have unveiled, known, listened, seen, felt Venice especially in recent years. Especially through the experience I have been living for seven years with the experimental Studio in Freiburg, an experience that, by revealing me other acoustic spectra, has given me other abilities to see and listen (Nono; Restagno 1993, p. 23). ${ }^{8}$

If the two musicologists insist on the influence of the urban environment in which Nono evolved during his whole life, it is because of the uniqueness of the archipelago city in the European cultural landscape. The geographical location of the city and the history of the Empire of which it was the capital for several centuries confer in fact a singularity justifying in itself its importance in the Western artistic imagination, which Sergio Bettini qualifies as a work of living art, like "all non-ordinary cities" (Bettini 2016, p. 27). Created without any topological constraint a priori, it is de facto a building whose formal structure does not obey any predetermination. Venice figures then a symbolic experience of art calling to be reinterpreted, conceived on the merge of a network of divergent practices and languages. That is why the architect envisages the city less as a simple urban and social construction than as a discursive model. As it is

\footnotetext{
${ }^{7}$ For example, in her philosophical evaluation of the ornament as an aesthetic category, Christine Buci-Glucksmann evokes the Baroque ornamental variation (see Buci-Glucksmann 2008, p. 18).

8 "Avant tout, je dois te dire que ce dévoilement continue encore aujourd'hui. Je te dirais justement qu'il me semble que j'ai dévoilé, connu, écouté, vu, senti Venise surtout ces dernières années. Surtout à travers l'expérience que je vis depuis sept ans auprès du studio expérimental de Fribourg, une expérience qui, en me révélant d'autres spectres acoustiques, m'a donné d'autres capacités pour voir et pour écouter."
} 
MUSICA THEORICA Revista da Associação Brasileira de Teoria e Análise Musical 2019, v. 4, n. 1, p. 160-187-Journal of the Brazilian Society for Music Theory and Analysis@ TeMA 2019 - ISSN 2525-5541

an open form in becoming, where every decision taken on structural and aesthetic criteria shapes the space of the lagoon from the foundations of the form to the realization of its adornment, Venice is the product of a sum of intentions whose coherence is not limited solely to functional criteria. According to Bettini, what is then to be referred to as the Venetian aesthetics is based on a fundamental principle of multiplicity. Indeed, it tends to encourage a centrifugal and reflexive vision of the structure:

The Grand Canal flows in successive meanders of curves, rounded and thus of uninterrupted expansions but not less contained, which also offer an experience, and thus a reading, of the radiation of the spaces that leave, or that converge ${ }^{9}$ (Bettini 2016, p. 79).

The oblique writing drawn from this example extends both "in a longitudinal direction (along the axis of our progression and our gaze) but also, could we say, transversally" (Bettini 2016, p. 81). The structuring of the space does not obey a flat geometry, it reveals itself by creating "counter-looks" (BuciGlucksmann 2008, p. 69) in the attention brought to these folds, in the manner of the Arabesque. To use the word of Bertaggia, the one who looks therefore becomes "himself protagonist not only of the execution, but also of the work of composition" (Bertaggia 1987, p. 134), modifying the shape of the Canal according to what he perceives in the plurality of perspectives.

This example then transcends the simple metaphor of illustration because it brings to light a complex spatial approach that all artistic practices originating in Venice integrate. What Bettini considers a "lateral expansion" is de facto a stylistic of the ubiquitous gap in the music of the archipelago since the Renaissance. The cori spezzati of 16th century written by the musicians who officiated at the Basilica San Marco is probably the most famous example: the dispersion of sources in space and the antiphonic writing direct the hearing towards a multi-axis development requiring an attentive listening opposed to the contemplation of a work arranged on the frontal plane of the Italian theatre. Examples of this configuration can also be found in the pictorial domain. As Jeannie M. Guerrero summarizes, “Tintoretto's foreground figures and

\footnotetext{
9 “Le Grand Canal s'écoule en méandres successifs de courbes, d'arrondis, et donc d'expansions ininterrompues mais non moins contenues, qui proposent également une expérience, et donc une lecture, du rayonnement des espaces qui en partent, ou qui y convergent."
} 
GOHON, K.

background architecture create a compound perspective rather than a single system of planes receding toward a single point" (Guerrero 2010, p. 26). As we will try to demonstrate with the analysis of Das atmende Klarsein and Risonanze Erranti, this plurivocal and reflexive logical approach can also be identified in Luigi Nono's electroacoustic works, in which the dislocation of the linguistic and conventional structures, the delayed projection of the instrumental voices in space and the altered image of the structures varied between the two types of writing that the composer summons generate a "lateral" listening similar to the "counter-looks" aroused by the Venetian ornamental mode.

\section{Towards a multidimensional ornamental structure in Das atmende Klarsein (1980-83)}

Das atmende Klarsein can be considered as the first work of Luigi Nono's late style, probably more than Fragmente - Stille, an Diotima. Not that the quartet does not announce certain features that the composer will develop in his last works, but it is not as representative as Das atmende Klarsein is to some extent, for its instrumental formation, the use of electronics it makes and the different sound and space concepts it testifies. Moreover, it establishes a reflexive logic between a traditional and pitch-based writing - that comes directly from his previous Works -, and the first elements of a new musical language based on perception and very precise sound variations. At first sight, the score is built on the opposition between "the hectic soli of the flute, based on the breath and its variations filtered by the live electronics, and the hieratic style of the pure voices of the choir with its consonant intervals and the permutation of the chords in space $^{\prime 10}$ (Albèra 2007, p. 323), echoing the ancient responsorial form. However, the treatment applied to the musical material and deployed throughout the score offers multiple ways to understand the structure, depending on the parameter we focus on.

\footnotetext{
10 “[...] l'opposition entre les soli mouvementés de la flûte, fondés sur le souffle et ses fluctuations, filtrés par la live electronics, et le hiératisme des voix pures du chœur, avec ses intervalles consonants et ses permutations d'accords dans l'espace".
} 
MUSICA THEORICA Revista da Associação Brasileira de Teoria e Análise Musical 2019, v. 4, n. 1, p. 160-187-Journal of the Brazilian Society for Music Theory and Analysis @ TeMA 2019 - ISSN 2525-5541

\subsection{A "pitch-based" ornamental variation}

Das atmende Klarsein is divided in eight sections - four written sections sung by the choir; three written sections and an improvised one that stands as a coda performed by the bass flute. The choir, which evokes the ancient Venetian cori spezatti11 - as it is mainly homophonic and artificially distributed in space with the help of an electronic device -, begins the work and exposes the initial material, which is built on different configurations of a fifth or a fourth associated to a minor second. As one can see in the first musical phrase (Ex. 1), these intervals underlie each melodic (horizontally) and harmonic (vertically) relationships in the polyphony. In this regard, the A on which the soprano line concludes the phrase is more likely related to the D sung by the contraltos, as it sets a fifth between the two voices and introduces the main cadential model used by Nono in this work. Then, it introduces every configuration of this initial intervallic material, from the most local level of the polyphony - where the intervals constitutes a referential cell of the melodic lines - to the largest structure of the section - the vocal introduction is led by an underlying harmonic progression evolving from $\mathrm{F} \#$ to $\mathrm{C} \#$ and goes back to $\mathrm{F} \#$, reinforced by the succession of an upward and a downward melodic movement.

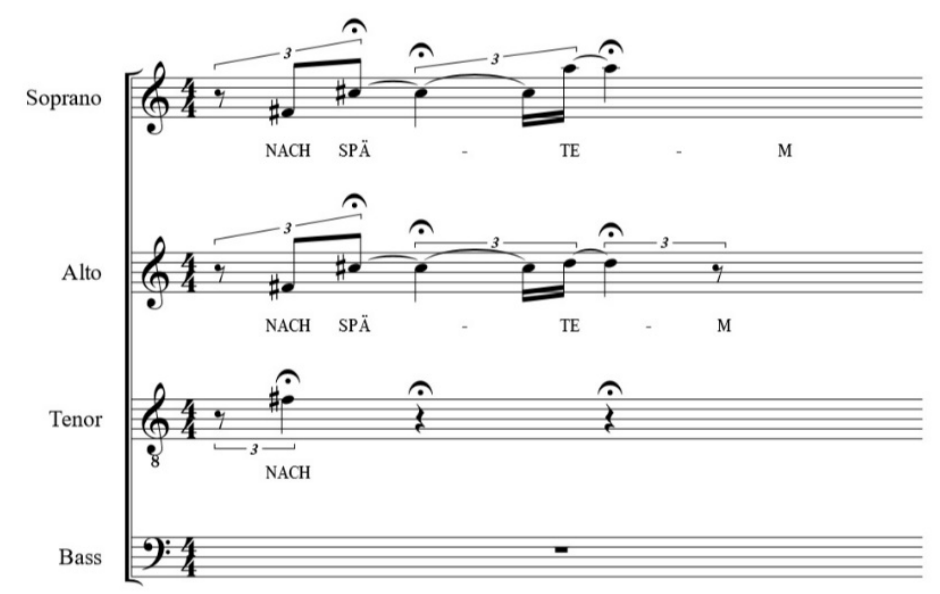

Example 1: first vocal phrase, choral introduction m. 1, Das atmende Klarsein

The next section, played by the flute, contrasts with the choir both by its length and the complexity of its melodic line. As it is illustrated in Example 2, the

\footnotetext{
11 According to Denis Arnold, "Homophony predominates, perhaps because it makes performances easier when choirs are distant from one another, certainly because imitative counterpoint would be less effective in such a mass sound" (Arnold 1959, p. 6).
} 
flute varies and expands the intervallic material, with the usual techniques of ornamentation. In the melodic dimension, the main pitches deducted from the application of the referential intervals starting on the initial $\mathrm{F} \#$ are separated with short melodic embellishments built from substitution pitches which incidentally implies another layer of melodic motives and intervals. For example, the main motive of the introductive gesture $(\mathrm{F} \#-\mathrm{B}-\mathrm{A})$ is intertwined with at least two triads involving the second pitch (F-E-B and $\mathrm{D}-\mathrm{E},-\mathrm{B})$ in the first measure and a motive built around $\mathrm{A}_{\sharp}(\mathrm{D}-\mathrm{A} \xi-\mathrm{A} b)$ which contradicts the cadential suspension on $\mathrm{A}$. Vertically speaking, some phrases use harmonic and multiphonic sounds in order to vary the cell by superimposing its pitches and different virtual melodic lines.
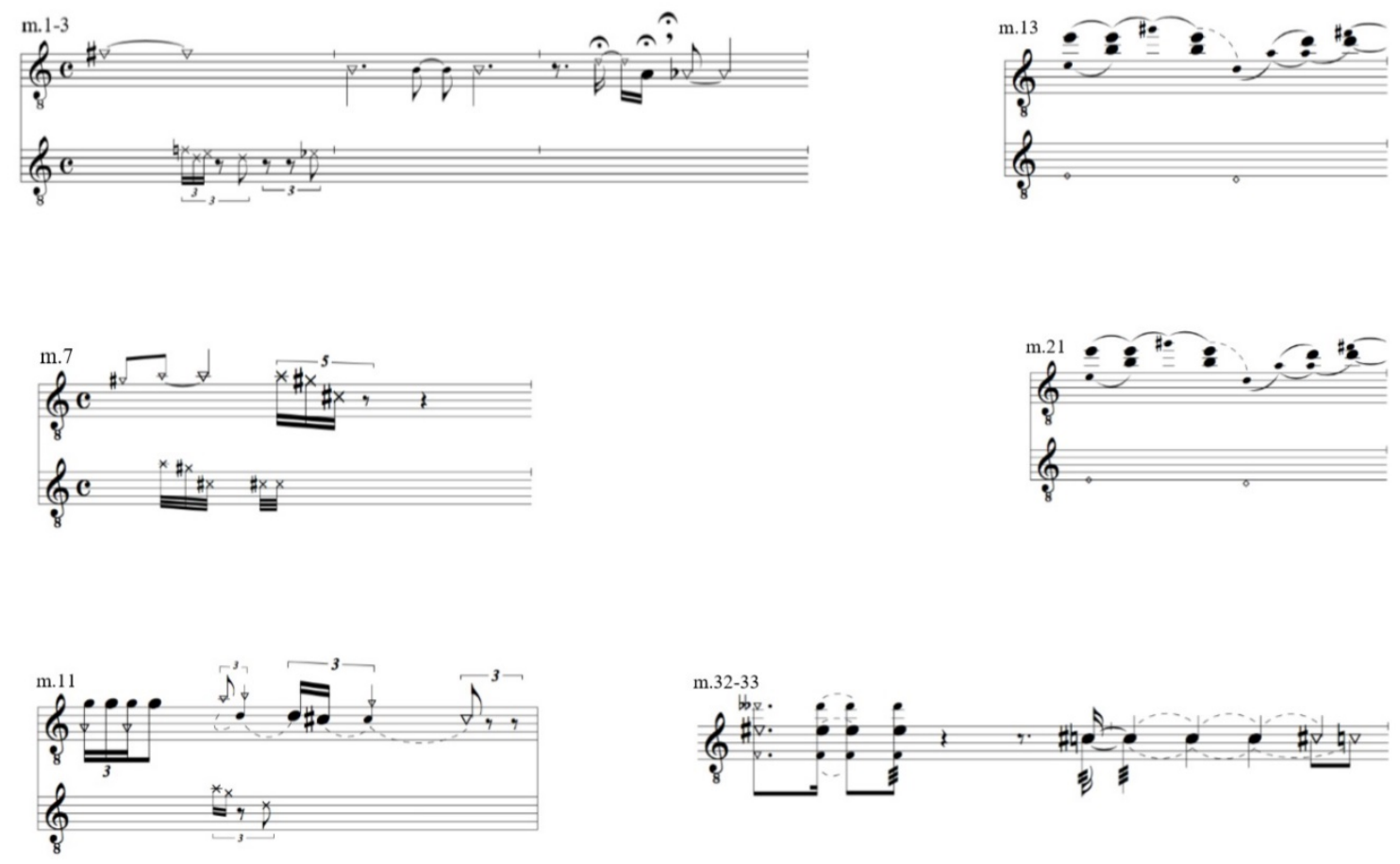

Example 2: Horizontal and vertical variations of the initial material in Flute section I,

Das atmende Klarsein

The second sections of the choir and the flute are related in the same way. The vocal writing is more complex and partially breaks the homophonic style exposed in the first section. Example 3 is an excerpt of choir section II. Indeed, the irregular distribution of the three text fragments - Aus Lust ins Freie / Siehe / عiт $\varepsilon \tilde{\mathcal{L}}$ - tends to create a contrapuntal configuration based on a dynamic pairing of the voices. While the first measure is strictly homophonic, the vocal texture becomes more complex and less constrained on the word "Freie". The 
relationship between tenors and basses is built on two kinds of polyphonic gestures. On the one hand, if the bass line sustains the $\mathrm{A}$, , one can consider that the phoneme [i] on which it enters has been anticipated by the tenor line, according to the strictly syllabic writing of the second choir. This textual anticipation can be considered as resolved as the tenor line joins the bass at the beginning of the next measure, on A,. On the other hand, in a more perceptible manner, the fact that the bass line sustains the $\mathrm{A}$, implies a suspension pattern with the tenor line. The relationship between the two upper voices is also led by a contrapuntal setting, though more complex than the one that has just been described. The soprano voice does not only complete the melodic line of the first phrase by establishing the fifth $\mathrm{A} / \mathrm{E} / \mathrm{E}$, while contraltos sustain "Frei-", it also echoes the final cadential triton $\mathrm{A} \approx / \mathrm{E}$, of the fragment.

This process is continued in choir section III, but with a different text setting that will be discussed further. The second flute section offers a new kind of ornamental variation of this writing process. Indeed, every phrase played by the flute is reintroduced twice into the speakers after a delay of 3 and 3.5 seconds respectively. Thus, one can consider that the contrapuntal style created by the electronic device are similar to the vocal writing of the previous choir section, even if the "text" is completely played by every voice - the real flute and the two virtual ones-: the texture is created with anticipations and suspensions created by the distribution of the same text in time and space.

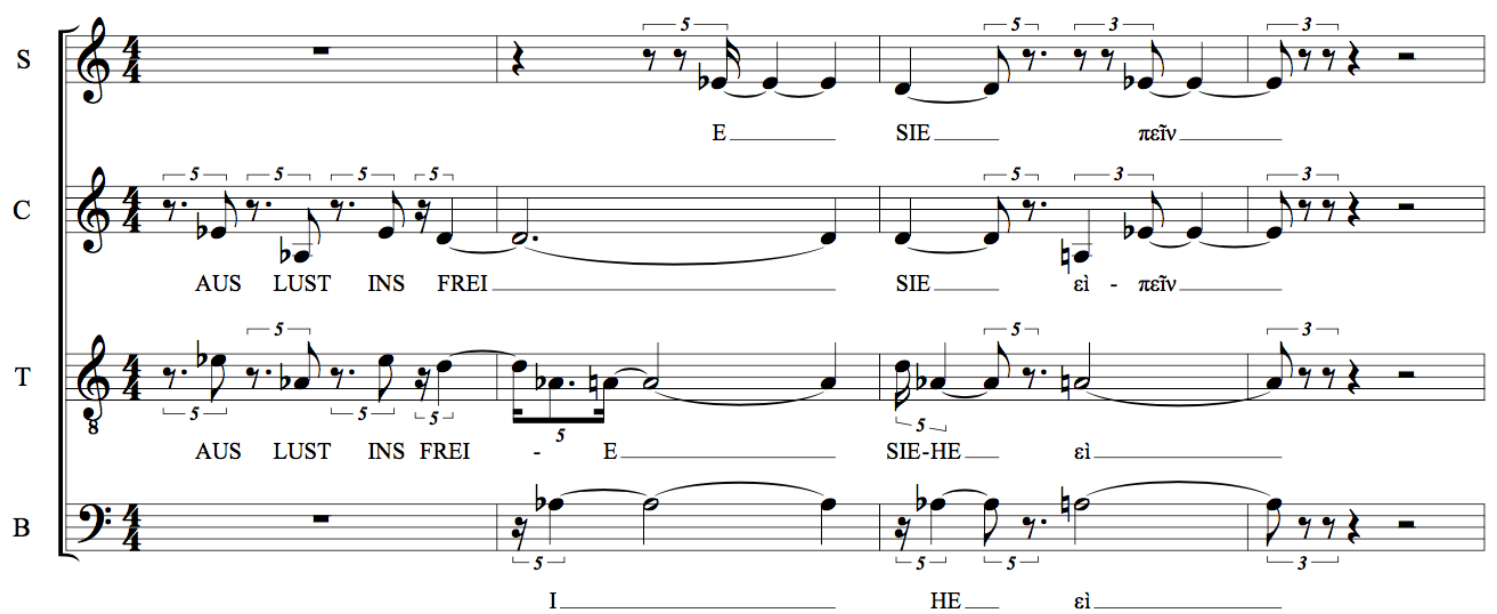

Example 3: Distribution of the notes and the syllables in Choir section II mm. 35-38, Das atmende Klarsein 
Once more, the third choir and flute sections present the same configuration. The voices develop the process heard before but the complexity of the vocal texture is now induced by the fact that different text fragments are sung simultaneously. Example 4 is an excerpt of the third flute section - which is its last written section in the score. The flautist plays all three staves simultaneously, without the support of any electronic device - the only electronic transformation used in this section is made of two static harmonizers that transpose the flute part a quarter note up and down. The bottom staff is the main line: it prescribes the fingering imposed to perform the other virtual voices, and its melodic line is the most intelligible one because of the modes of emission it summons. The second line is built on "eolien"12 harmonics, which follow the rhythm of the main line almost systematically but vary the pitches. The third line is made of whistle tones with both absolute and relative pitches and rhythms. Hence, one can consider that it is an ornamental variation of the vocal writing developed in the technical repertoire of the flute: the entire section is based on a homophonic writing but the texture is locally more complex because of the coincidental simultaneity of the three independent lines that develop their own texture.

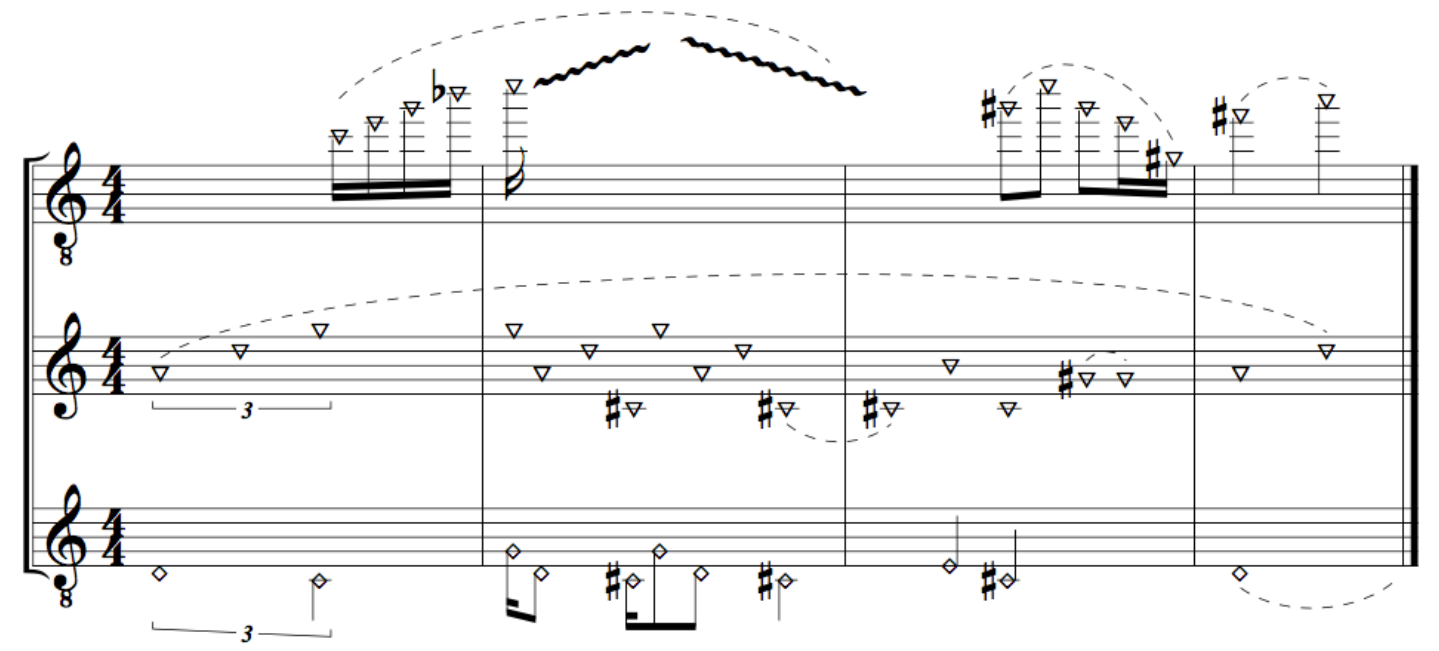

Example 4: Distribution of the notes in Flute section III mm. 13-16, Das atmende Klarsein

Thus, as the first three flute sections are built on variations of the writing processes developed in the first three choir sections, one can understand the

\footnotetext{
${ }^{12}$ As André Richard and Marco Mazzolini explains in the score of Risonanze erranti, "the term 'eolien' used by Nono means 'wisthle-tones': the eolien are therefore very high partials, isolated and reinforced within a given sonic spectrum. The fundamental sound appears and disappears like a shadow ('shadow sound')" (Richard; Mazzolini 2015, p. XXVIII).
} 
MUSICA THEORICA Revista da Associação Brasileira de Teoria e Análise Musical 2019, v. 4, n. 1, p. 160-187-Journal of the Brazilian Society for Music Theory and Analysis@ TeMA 2019 - ISSN 2525-5541

relationship between the choir and the flute as a long ornamental variation according to Schoenberg's definition:

One can distinguish two methods of varying a motive. With the first, the variations usually seem to have virtually nothing more than an ornamental purpose; they appear in order to create variety and often disappear without a trace $[\ldots]$. The second method can be termed developing variation. The changes proceed more or less directly toward the goal of allowing new ideas to arise (Schoenberg 1917, p. 38-39; Schoenberg 2006, p. 247).

The understanding of the musical structure of Das atmende Klarsein as an ornamental variation is a result of a pitch-based analysis, which only considers the diagrammatic symbolic notation of the written score. However, the material and variation processes of Das atmende Klarsein cannot be understood through the analysis of its pitches and durations systems, as Nono's writing is mainly based on the experimentation of sound parameters and specific timbres.

\subsection{A "sound-based" developing variation}

As mentioned previously, the flute writing develops a sound-based discourse made of fluctuations of breath rather than a pitch-based one, which is mainly attributed to the choir. Returning to Example 1, with this in mind, the first flute section seems to be based on two different kinds of variation: the expansion based on the usual ornamentation process that has been identified previously and a variation of the initial cell in the sound domain. Indeed, as a result of Nono's research of new sound possibilities in his music, it appears that almost each note played by the flutist uses a different mode of emission. Thus, the pitchbased expansion of the motive is hidden by the diversity of the sound qualities because the pitches cannot be distinctly heard. This is particularly apparent in Example 1. Moreover, the different sounds played by the flute and scaled from the usual timbres of the instrument to a complete breath induce a particular hierarchy that influences the listening.

One can distinguish therefore a large-scale phrasing marked by the recognizable "pitched sound" of the flute, which partially contradicts the pitchbased writing identified previously and sounds adorned and enhanced by the breathy and unpitched sounds. Regarding the homophonic style of the first choir section, the flute section will be heard as an increasing of the sound complexity opposed to the pure and homophonic sound of the choir whereas the writing 
processes remains homogeneous throughout both sections. This flute section then appears to be related to the second choir section in a new way: one can relate the vertical distribution of the syllables of each text fragment that break the homophonic style with the large-scale structure of the flute section as it presents a musical phrase expanded by an increasing complexity in the sound domain.

The polyphonic writing of the choir previously presented even seems to be linked to the cells of the flute written in whistle tones in the vertical variations presented in Example 1. The different notes that form the musical phrase are presented with suspensions and anticipations that create a particular polyphonic writing and announce the text distribution highlighted in Example 2. Once again, the second flute section and the third choir section can be related in a similar way: if the second flute section unfolds a writing process similar to the one exposed in the previous choir section, it also varies it by a sound oscillation between breath and pure note. Once again, it leads the writing to more complex sound qualities. In a certain way, it is continued in the third choir section. Considering that there is no change operated in the writing process between the flute and the choir section, the variation is almost only contained in the sound domain and induced by the superimposition of the different text fragments. The vocal treatment is then formed on the sound characteristic of the syllables, their "timbre", with almost no consideration of their meaning.

Consequently, the pitch-based writing inherited from the serial technique, mainly built on permutation, transpositions and motivic variations of a limited material, seems to be gradually forsaken in favor of the expansion of the sound dimension of the music, which leads to the particular device of the last section of the work. Indeed, this section is built on a particular ornamental structure that evokes the arabesque as the flautist has to improvise and interact with a tape recorded with sounds that he played in the previous sections: he unfolds therefore a musical line that is based on the sound material he played before, and the person in charge of the sound direction has to interact with what he hears by adjusting the dynamics of the tape and its movements in space accordingly. Luigi Nono will further explore this setting of structural ornamental relationship in its soloist works as La Lontananza Nostalgica Utopica Futura (1988).

From this perspective, one can define Das atmende Klarsein as a soundbased developing variation, according to Schoenberg's second method: each section of the flute increases the sound complexity of the writing processes 
MUSICA THEORICA Revista da Associação Brasileira de Teoria e Análise Musical 2019, v. 4, n. 1, p. 160-187-Journal of the Brazilian Society for Music Theory

developed in each choir section, and each choir section seems to be influenced by sound richness of the flute sections, which heterogeneity is echoed by the increasing fragmentation and discontinuity between the lines of the polyphony, both in their harmonic relationship and in the treatment of the poem. Furthermore, the writing processes do not affect the initial cell in the usual way - it is almost not varied in the "pitch-domain" and can be found in its original form until the end of the score - but are only developed in terms of sound complexity: the bass flute uses a wide range of modes of emission and electronic transformations and the vocal treatment tends to exploit the sound qualities of the phonemes only. By setting up the flute and the voices as an heterogeneous reservoir of acoustic and sound resources used to vary the initial cell - which is preserved throughout the score -, Das atmende Klarsein exposes one of the project that will be developed in the composer's late works, namely to free the ear "from its visualizing, selective and unidirectional habits, in an almost ritual manner, according to the wide diversity of the acoustic life, which constantly accompany us“(Nono 2007, p. 524). ${ }^{13}$

This kind of multidimensional structure is not only developed in this first work of Nono's late style, but can be found in each vocal work written by the composer during the last ten years of his life.

\section{Rethinking the musical discourse in the light of the ornamental phenomenon: the case of Risonanze erranti (1987)}

If Das atmende Klarsein introduces the main elements of Luigi Nono's late style, the work is not actually representative of the works created in the ten last years of the composer's life, especially in terms of musical discourse and space conception of music: even if it is developed in a new musical dimension, the fact that the piece is entirely directed towards an increasing of complexity - whether related to a motivic or a sound domain -, which ends with a return to silence, evokes the traditional model of conducting a musical phrase according to the arsis-thesis sequence, or, as Claude Abromont highlights it, the tonal phrasing of the melodic cell organized around the triad "anacrusis [anacrouse], emphasis

13 "La perception et l'écoute peuvent être rendues plus difficiles, mais à la vérité, elles peuvent vraiment libérer les oreilles des habitudes monodirectionnelles, visualisantes et sélectives, de manière presque 'rituelle', par rapport à la très riche variété de la vie acoustique qui nous accompagne sans cesse." 
[accent], inflexion [désinence]" (Abromont; De Montalembert 2008, p. 140). Nevertheless, some of the works written after Prometeo seem to reuse the developing variation principles in order to create a new kind of structural relationship between the voice and the instrument - or between a pitch-based and a sound-based approach -, and extends it to an upper formal level between sound and space, as it is the case of Risonanze erranti (1986-87), written for a mezzo-soprano, a bass flute, a tuba and six percussionists.

\subsection{A new ornamental relationship between pitch and sound}

The score is composed of five groups of fragments taken from literature one group is based on excerpts of Ingeborg Bachmann's Keine Delikatessende and another one on Herman Melville's poems - or from musical works - Mahleur me bat written by Ockeghem, Josquin's Adieu Mes Amours or Machaut's Lay de Plour - and creates two interwoven conceptual spaces from the characteristic of the voice and the instruments, in a way that is reminiscent of Das atmende Klarsein. The first one can be termed as a semantic space: it unfolds a pitch-based musical discourse and contains the text fragments set to music in a way that makes them sufficiently recognizable to activate the listener's language memory, as well as the different musical quotations. On this basis, the different idiomatic and figurative materials echoing a traditional way to conduct the musical discourse can be declined in this space. The second space is a sound space and unfolds the writing tools characteristic of the late style of the composer: the development of a wide range of modes of emission, the electronic sound transformations that expand a sound by simultaneously transposing it a quarter-tone up and down, and the exploitation of text fragments that only use the sound qualities of phonemes. The musical discourse can then be understood as the articulation of different combinations of these two conceptual spaces, which conducts the variations of the fragment groups.

Example 5 outlines the different materials attributed to the two spaces in the Bachmann fragment group. The five fragments are distributed throughout the score. The first fragment of the group is only exposed in the sound space: there is no musical phrase and the different notes and chords are separated by long silences. Furthermore, the three words sung in this fragment present a similar structure and are best heard as three successive variations of the timbre characterized by a brief attack (" $n-{ }^{\prime \prime}$ and " $\left.m-{ }^{-}\right)$, a sustained closed vowel (/' $\mathrm{I} /$ in 
MUSICA THEORICA Revista da Associação Brasileira de Teoria e Análise Musical 2019, v. 4, n. 1, p. 160-187-Journal of the Brazilian Society for Music Theory and Analysis @ TeMA 2019 - ISSN 2525-5541

"Nicht" and "Mir", and /'e:/ in "Mehr") and a noisy and brief stop (/çt/ and /r/) than three intelligible words. Hence, one can consider the semantic space as an ornament of the sound space in this fragment as it is set up as a figurative embellishment of the sound of the voice. The second and the third fragments propose two different semantic variations of Bachmann. In the first one, the flute develops a long and regularly pulsated melodic line built on a succession of sequences, each clearly identified by a phrasing shape and dynamic shades. Even if the reference to Keine Delikatessen is never presented in the fragment, except for its title in the score, it is highly suggested by the homophonic texture realized with an instrument characterized by the proximity of its inflections with voice, and by the fact that the musical processes unfolded in this fragment echo a traditional expressive approach which contrasts with the erratic and nondirectional nature of Risonanze erranti musical discourse.
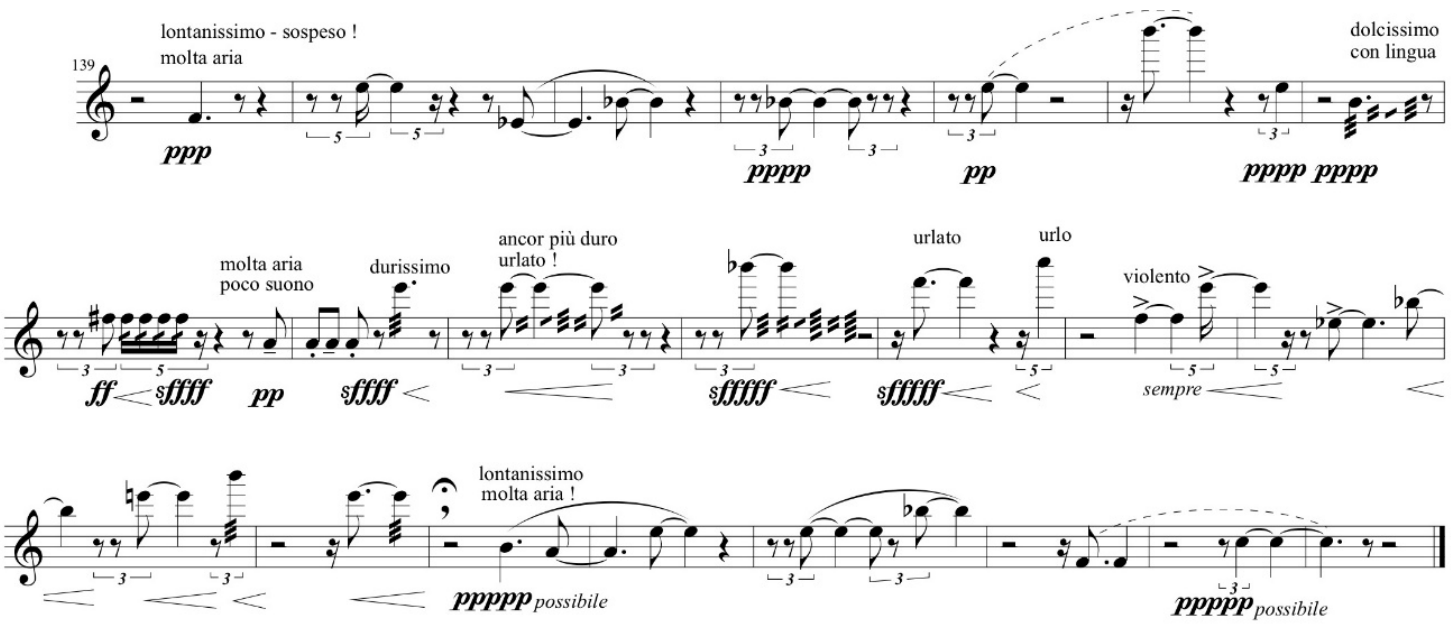

Figure 1: Piccolo part, Bachmann 2, mm. 139-160, Risonanze erranti

Bachmann 3 then synthetizes the configuration of the two first fragments. The text returns, but it is faded in a recto tono based on the alternation between the trombonist, the flutist and the mezzo-soprano in order to create a continuous pitch in which the words are not only a literary content, but also integrates a cyclic dynamic process that one can define as a sound-based musical gesture. Indeed, the first four vocal interventions are based on two syllables echoing the similarity of "Nicht", "Mir" and "Mehr" in Bachmann 1. Due to the expression indication - "dentro al microfono, quasi solo fiato-pochissimo suono, molto articulate le consonanti" -, the words "einsehn", "gelernt", "hunger" and "tränen" appears as modes of articulation of the recto tono. In this perspective, the musical gesture 
can also be understood as a complete phrase, as the word "finsternis" interrupts the cyclic process in terms of metric structure and homogeneity but it is logically implied by the text and integrated in the recto tono.

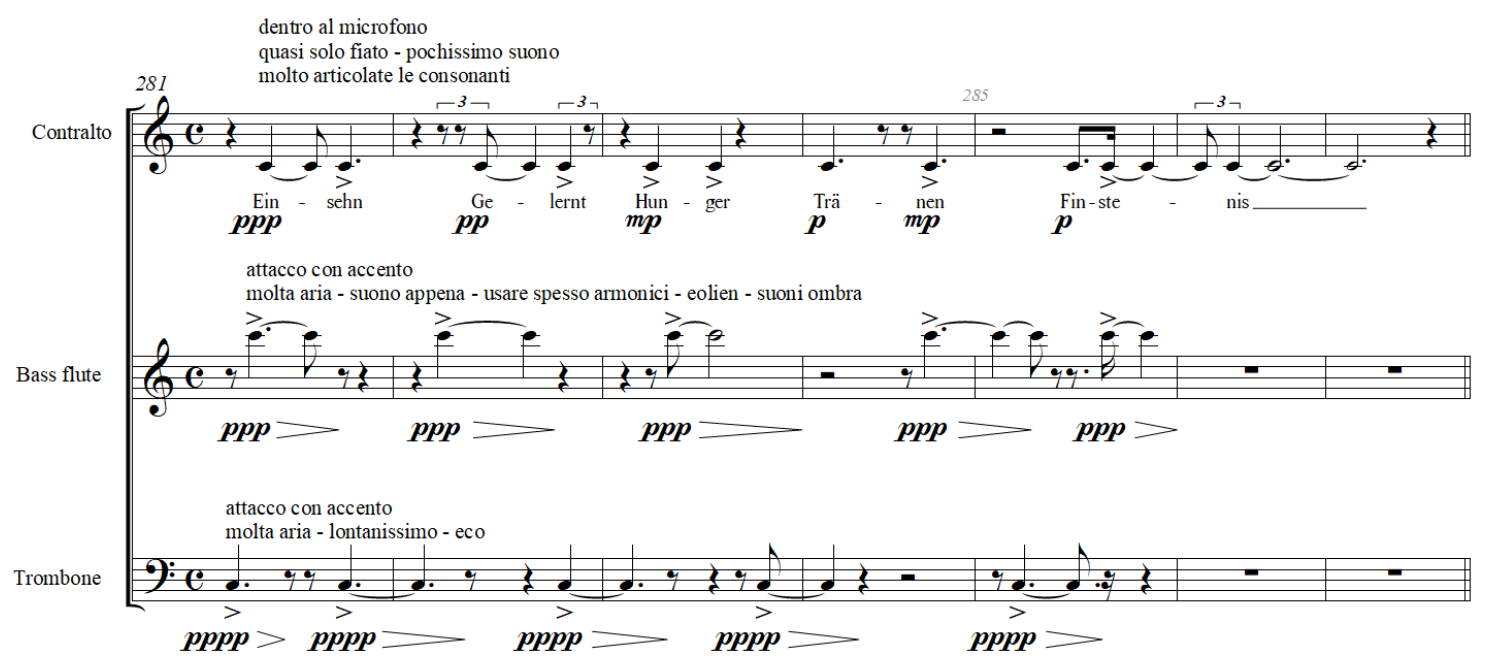

Figure 2: polyphonic distribution, Bachmann 3, mm. 281-287, Risonanze erranti

In the fourth fragment, the relationship between the two spaces seems to be overturned. The musical material is almost entirely contained in the semantic space as the voice sings an intelligible text split in two musical gestures with a melodic gesture that echoes the flute in the second fragment, as the vocal line is irregular, disjointed and contrasted. ${ }^{14}$ The sound space only outlines the voice with electronic transformations and punctuates the fragment with the last two words ("Noch" and "Vor") written in the vocal model of Bachmann 1. Finally, the two spaces appear to be equally distributed in the last fragment, which lasts almost six minutes and ends the work. On the one hand, the instrumental parts develop the recto tono heard in the third fragment with different modes of emission and a dynamic profile reminiscent of Bachmann 2 - as the musical texture is formed by isolated pitches in a series of short crescendos and contrasted dynamics. On the other hand, the words sung by the voice are intelligible, but the text is only made with the German personal pronouns ("ich, $d u$, er, sie, es, wir, $\left.i h r^{\prime \prime}\right)$ and it is scattered in time, without any phrase-oriented mode of organization. Thus, if each fragment seems to present an original configuration

14 The harmonic material of the phrase is also based on semitones and fourth/fifth as it is introduced in Bachmann 1 and developed in Bachmann 2. 
MUSICA THEORICA Revista da Associação Brasileira de Teoria e Análise Musical 2019, v. 4, n. 1, p. 160-187-Journal of the Brazilian Society for Music Theory and Analysis@ TeMA 2019 - ISSN 2525-5541

of the two conceptual spaces, the entire group is set up as a developing variation that unfolds the semantic space with the materials exposed in the sound space. In the same perspective, the Ockeghem fragment group progresses towards the semantic space: the famous phrase "Malheur me bat" is performed first by the crotales - Nono uses the text to guide the phrasing in the manner of FragmenteStille-, and it becomes more intelligible in the other fragments as the voice sings "-lheur me" in the second one and "Malheur" in the last one.

On the contrary, Josquin fragments unfold an opposite developing variation, which is oriented towards the sound space. Example 6 summarizes the materials and their distribution between the two spaces in the five fragments of the group. In the first fragment of the group, the sound space has no other function than to accompany the musical quotation of Josquin's work sung by the voice and doubled by the flute and the tuba. In Josquin 6, the structure is inverted: the text is split in two cells that evoke the variations of the timbre mentioned previously about Bachmann 1; the phrase played by the tuba is also split and the sound spectrum is more complex due to the different modes of emission and the dynamic curve applied to the percussion instruments. The next fragments continue the process, even if the semantic space is more active in Josquin 10 than in Josquin 9 because the musical phrases are based on the complete quotation of "Adieu mes amours". Finally, the last iteration of the quotation is only contained in the sound space, even if the performance of the crotales is guided by the text "Adieu". The group formed with Machaut's quotation is similarly organized.

Hence, Risonanze erranti unfolds a new kind of musical discourse by superimposing different developing variations based on the writing processes introduced in Das atmende Klarsein. The distribution of the fragments in the score continuously breaks the variation dynamic and avoids directing the work towards one conceptual space or the other. Thus, they appear as two adjacent lines that locally meet and adorn the other one, but without succumbing to it. Then, it reveals the gap between the two spaces without leading the listening in favor of one or the other and it engenders a counter-listening - as an analogy to Christine Buci-Gluckmann's "counterlook" - of "the close and the distant, devoid of any illusion and perspective, without a hold on things, similar to infinity" (Buci-Glucksmann 2008, p. 67), which originates from the Byzantine ornamentalism omnipresent in Venice, according to the philosopher. 


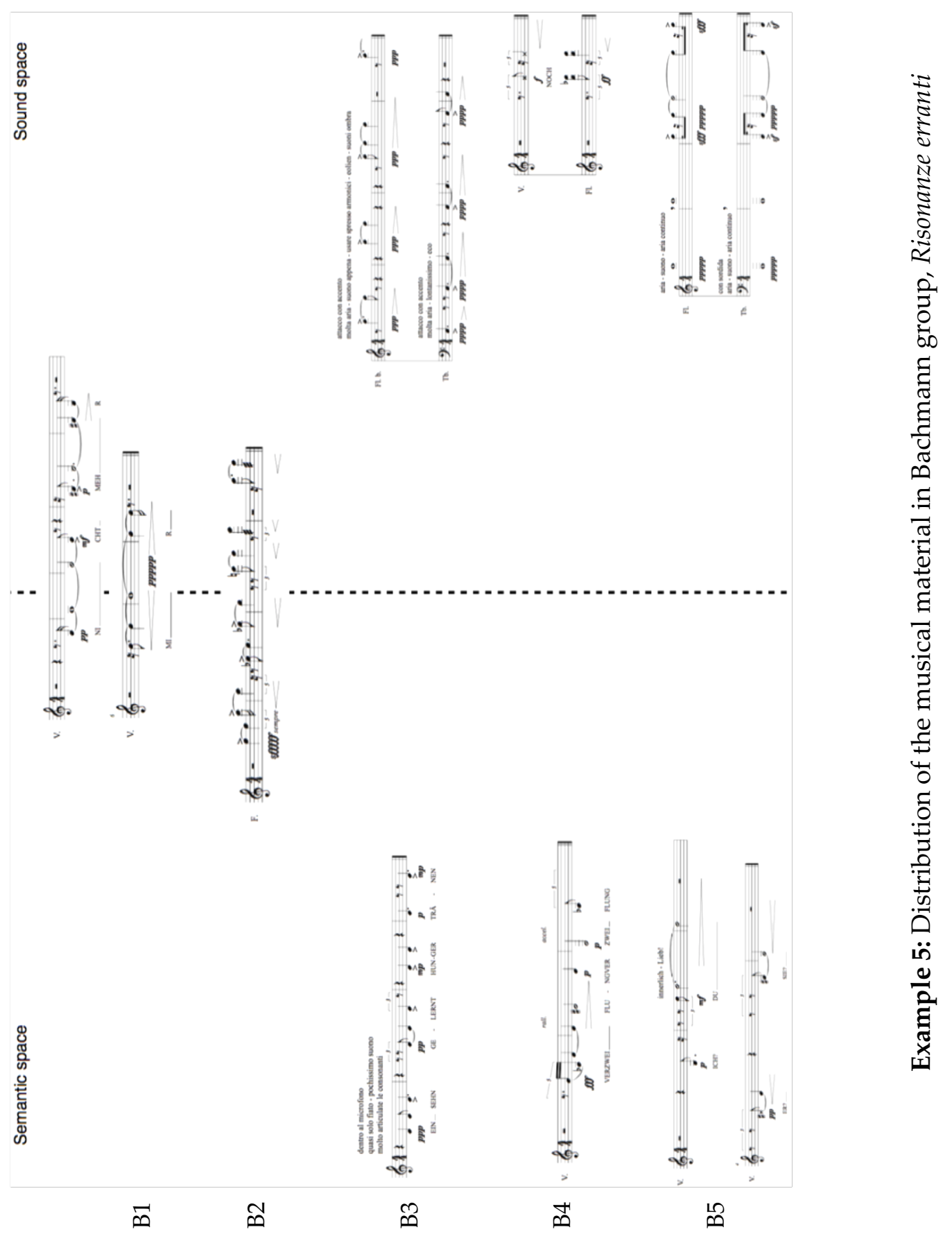


MUSICA THEORICA Revista da Associação Brasileira de Teoria e Análise Musical 2019, v. 4, n. 1, p. 160-187-Journal of the Brazilian Society for Music Theory and Analysis @ TeMA 2019 - ISSN 2525-5541

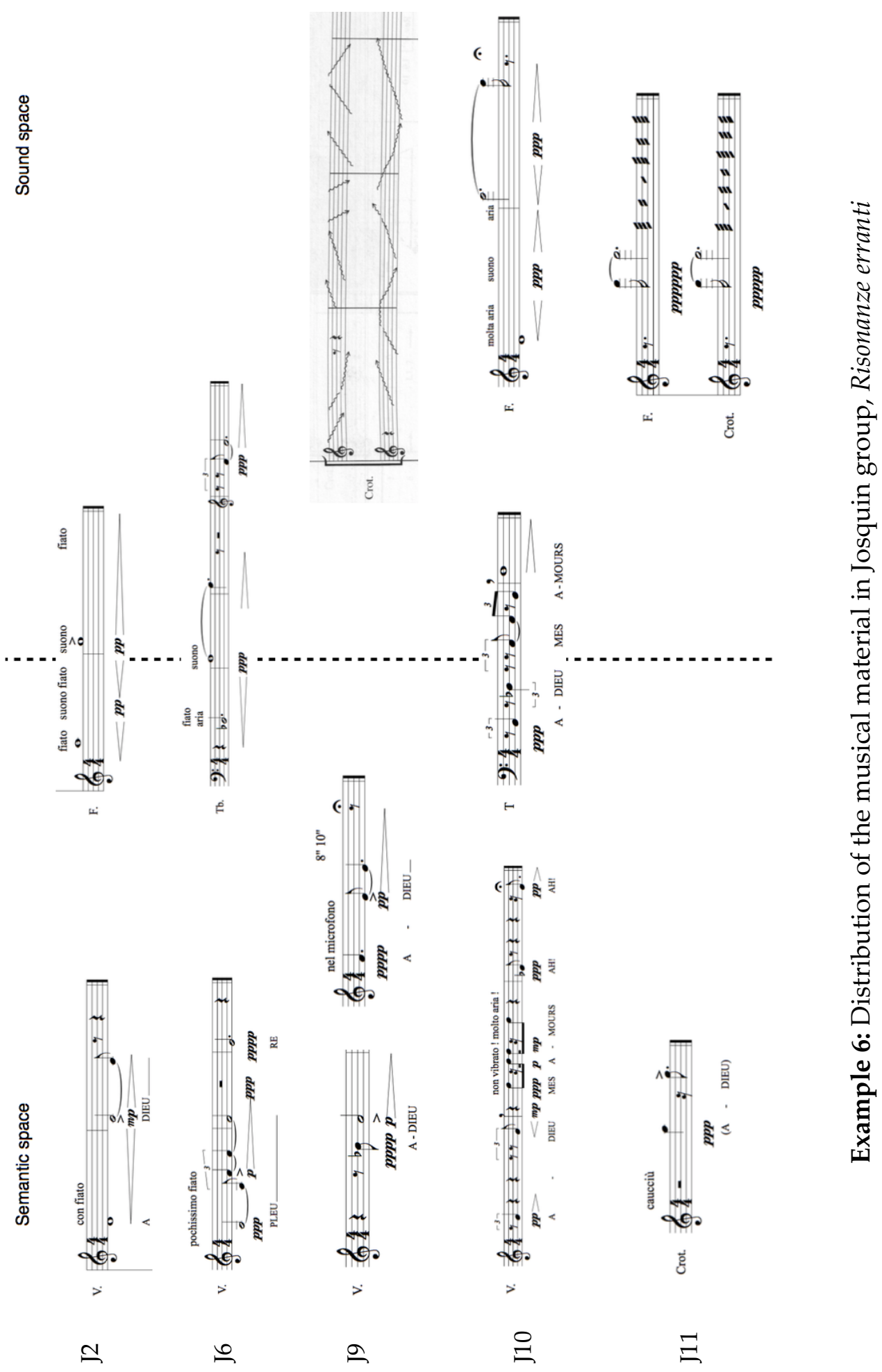




\subsection{Towards the musical discourse as an ornament of space}

Risonanze erranti cannot be reduced to the relationship between the semantic and the sound space. These two conceptual spaces form de facto a dynamic texture that conducts the same kind of relationship with the spatial feature of the work. The spatial dimension of the score is not only represented by the use of a dynamic electronic spatialization, but also with specific motives played by the percussion instruments. It is almost silent, with unpitched sounds and the rhythm and the sources of emission are unrecognizable because of the two delay lines combined to the distribution and the movements of the sounds between the loudspeakers. One can de facto define this motive as an ornament of space according to the fact that it accomplishes the dynamic spatialization in the sound domain and is only dedicated to the representation of the spatial component of the work, a true "reading of space" (Bertaggia 1987, p. 144). Example 7 details two patterns of the motive.

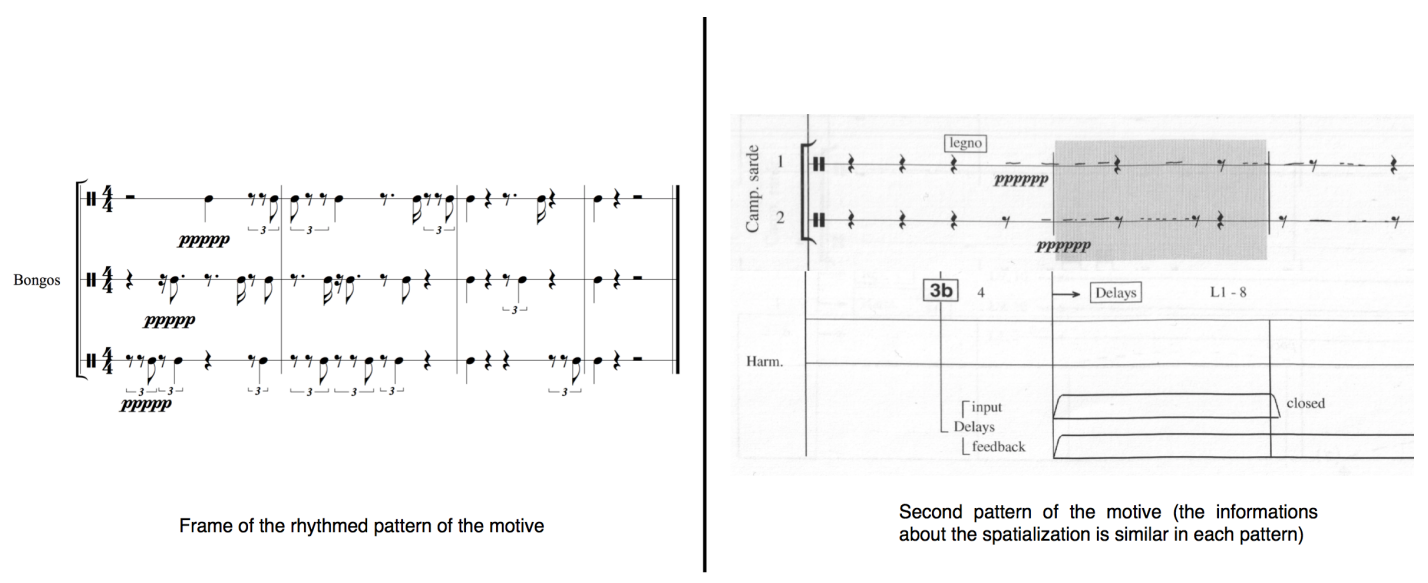

Example 7: Two patterns of the "ornament of space" motive, Risonanze erranti

The first pattern appears in the first five fragments of the work in alternation with the vocal phrases based on Melville's Misgivings poem, but it cannot be considered as a sound material of the fragment group as it is excluded from the writing processes of the group. This motive - now in the ornamental meaning of the term - is then set as an independent musical object that punctuates the writing developments between the sound and the semantic spaces identified previously. The alternation slowly disappears as the motive intertwines with the fragments. The second pattern can be heard after the first Ockeghem fragment and accompanies a Melville's fragment. However, this "sound ornament of space" and the dynamic figures of spatialization associated 
with it extend and locally split, generating different variations of the motive in contact with the sound or the semantic space. The space seems actively involved in the Machaut fragments group. In Machaut 4, the motive separates the two instances of the repeated phrase "Ahimé". As shown in Example 8, it is built on the superimposition of two variations of the second pattern played by the Sardinian bells and the crotales. The dynamic distribution of the space, though, is not only limited to the motive: the voice is also distributed in the loudspeakers and successively forms two inverted circular figures. Hence, the spatialization is used in two ways: on the one hand, it is set as a manifestation of the spatial texture of the work, which is very dynamic and ungeometrical - represented by the sound motive. On the other hand, there is a spatial ornament of the semantic space that evokes a geometrical figure, which is superimposed on the spatial texture. The second and the fifth fragments continue this process with a different spatial ornamental figure applied to the sound space. Finally, the only representation of the spatial component of the work in the fourth fragment is the initial spatialization pattern applied to a different sound material, without the motive. This double dimension can also be found in Josquin group.

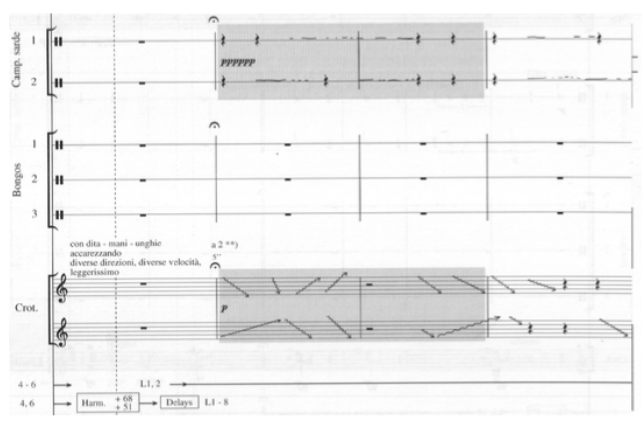

"Ornament of space", m. 105-108
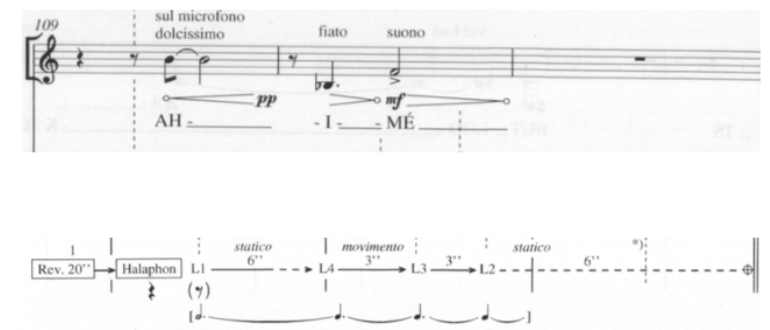

Spatial ornament of the voice, m. 109-111

Example 8: ornament of space and spatial ornament of the semantic space in Machaut

\section{4, Risonanze erranti}

To these elements must be added a third variation of the motive that complexifies the perception of the space in this piece. The "ornament of space" can be found several times in the percussion parts, but without any electronic spatialization. For example, the sound material of the third Machaut fragment is almost entirely formed by the rhythmic pattern of the motive statically projected in front of the audience with a dynamic profile oscillating between $p p p p p$ and fff. 
The ornament of space is then used as a different kind of ornament of the sound space as, in this case, it only exploits the sound qualities of the motive - which is set as a sound representation of the space -, contrary to the previous variation that uses a spatial figure to adorn the sound and the semantic space. This variation can be found repeatedly throughout the score and creates, thereupon, a dialectic relationship between the spatial and the sound dimension of the motive. This dialectic culminates in the last three fragments of the piece, in which the two patterns of the motive can be heard with and without the delays and the spatialization. Thus, as it is emancipated from its usual figurative and "geometrisable" - in the Euclidian meaning of the term - representation, the spatial component of the work allows the listener to experience a "true listening" of the space, according to Massimo Cacciari:

a conditioned listening, which resolves itself in the 'belief', is reduced to a visualizing listening of metaphors and constitutes a limited form of research that impedes the possibilities of perception and thus of a true listening (Bertaggia 1987, p. 137). ${ }^{15}$

Finally, the entire musical discourse of Risonanze erranti is built on an ornamental logic, a "specifically artistic manner of a recursive process of distinction" (Golsenne, A. et al., p. 11-26) according to Michael Dürfeld's definition. Indeed, as it unfolds multiple dimensions of space that locally meet and enlighten each other, resonate in each other, but don't change in favor of one or another, the work wanders between musical representations of the multiple dimensions of a concept of space which cannot be positively presented, establishing a "genuine stylistic of the gap in which the nihil atopia turns into [...] a vibrant figure", to borrow the expression that Christine Buci-Glucksmann uses to define the Venetian vision of the ornamental phenomenon.

\section{Conclusion}

The new features that Luigi Nono develops in his late works seem to be related to the ornamental phenomenon in many ways. On the one hand, the fact that the traditional techniques of ornamentation are unfolded in the sound

\footnotetext{
15 “[...] une écoute conditionnée, qui se résout dans la 'croyance', se réduit à une écoute visualisée de métaphore, constituant une forme de recherche limitée qui entrave les possibilités mêmes de la perception et partant, d'une véritable écoute..."
} 
domain in order to realize the well-known "mobile sound" in Das atmende Klarsein testifies a form of denial of the traditional ornamental manifestation in music by deflecting it from its figurative function. On the other hand, it has been demonstrated in Risonanze erranti that the work itself can echo an ornamental function considering its relationship with Nono's multidimensional and "ungeometrisable" conception of space, as it summons a "representative language of what escapes to the representation" (Buci-Glucksmann 2008, p. 77). Thereupon, the work avoids any narrative or discursive form as it only enlightens the multiple dimension of space in a negative way, on their periphery. With Luigi Nono, the music becomes an ornamental line, a virtual surface in which the heterotopias that form the space collide and allow them to be only heard through a differential listening.

\section{References}

1. Abromont C.; De Montalembert E. 2008. Guide de la théorie de la musique. Paris: Fayard/Henry Lemoine.

2. Albèra Philippe. 2007. Le Son et le Sens. Essais sur la musique de notre temps. Genève: Contrechamps.

3. Albèra Philippe. 1987. Entretien avec Luigi Nono. Luigi Nono 1987. Paris: Contrechamps/Festival d'Automne à Paris, p. 13-22.

4. Arnold Denis. 1959. The significance of "Cori Spezzati". Music E Letters, v. 40, n. 1, p. 4-14.

5. Borio G.; Morelli G.; Rizzardi Veniero. 1999. La nuova ricerca sull'opera di Luigi Nono. Firenze: Olschki.

6. Bertaggia Michele. 1987. Prometeo - Conversation entre Luigi Nono et Massimo Cacciari. Luigi Nono 1987. Paris: Contrechamps/Festival d'Automne à Paris, p. 132-146.

7. Bettini Sergio. 2016. Venise. Naissance d'une ville. Trans. by Farazzi P. Paris: L'Éclat.

8. Buci-Glucksmann Christine. 2008. Philosophie de l'ornement. D'Orient en Occident. Paris: Galilée.

9. Carboni Massimo. 2012. Ornement et Kunstwollen. Images Re-vues, v. 10, http://journals.openedition.org/imagesrevues/2032. 
10. Dewitte Jacques. 2005. Le sens ontologique de l'ornement. in Laroque D.; Saint Girons B. (Eds.). 2005. Paysage et ornement. Paris: Verdier, p. 39-48.

11. Dewitte Jacques. 2010. La manifestation de soi. Eléments d'une critique philosophique de l'utilitarisme. Paris: La Découverte.

12. Edwards Peter I. 2008. Object, Space, and Fragility in Luigi Nono's Das atmende Klarsein. Perspectives of New Music, v. 46, n. 1, p. 225-243.

13. Feneyrou Laurent. 1993. Introduction. in Nono Luigi. 1993. Ecrits. Paris: Bourgois.

14. Gadamer Hans G. 2018. Vérité et méthode. Les grandes lignes d'une herméneutique philosophique. trans. By Fruchon Pierre; Grondin J.; Merlio G. Paris: Seuil.

15. Geiger F.; Janke A. (Eds.). 2015. Venedig, Luigi Nono und die komponierte Stadt. Zur musikalischen Präsenz und diskursiven Funktion der Serenissima. München: Waxmann.

16. Griffiths Paul. 2010. Modern music and after. 3rd ed. New York: Oxford University Press.

17. Golsenne Thomas. 2012. L'ornement aujourd'hui. Images Re-vues, v. 10, http://journals.openedition.org/imagesrevues/2416.

18. Golsenne T.; Dürfeld M.; Roque G.; Scoot K.; Warncke C.-P. 2010. L'ornemental: esthétique de la différence. Perspective, v. 1, http://journals.openedition.org/perspective/1200.

19. Grabar Oleg. 1996. Penser l'art islamique. Une esthétique de l'ornement. Paris: Albin Michel.

20. Guerrero Jeannie Ma. 2010. Non-Conventional Planar Designs in the Works of Nono and Tintoretto. Music Theory Spectrum, v. 32, n. 1, p. 26-43.

21. Laroque D.; Saint Girons B. (Eds). 2005. Paysage et ornement. Paris: Verdier.

22. Loos Adolf. 2015. Ornement et crime. trans. by Cornille S.; Ivernel P. Paris: Payot-Rivages.

23. Melkert Hella. 2001. "Far del silenzio cristallo": Luigi Nono, Chorkompositionen im Rahmen des "Prometeo". Saarbrücken, PFAU Verlag.

24. Morgan David. 1992. The Idea of Abstraction in German Theories of the Ornament from Kant to Kandinsky. The Journal of Aesthetics and Art Criticism, v. 50, n. 3, 1992, p. 231-242.

25. Nielinger-Vakil Carola. 2016. Luigi Nono. A composer in context. Cambridge: Cambridge University Press. 
MUSICA THEORICA Revista da Associação Brasileira de Teoria e Análise Musical 2019, v. 4, n. 1, p. 160-187-Journal of the Brazilian Society for Music Theory and Analysis @ TeMA 2019 - ISSN 2525-5541

26. Nono Luigi. 1993. Écrits. trans. by Feneyrou L. Paris: Christian Bourgois.

27. Nono Luigi. 2007. Écrits. trans. by Feneyrou L. Genève: Contrechamps.

28. Nono Luigi. 2007. Das atmende Klarsein. 139378. Milan: Ricordi.

29. Nono Luigi. 2015. Risonanze erranti. 139646. Milan: Ricordi.

30. Nono L.; Restagno E. 1993. Une autobiographie racontée par l'auteur. In Nono L. 1993. Écrits. Paris: Christian Bourgois.

31. Ramazzotti Marinella. 2007. Luigi Nono. Palermo: L'Epos.

32. Reissig Elfriede E. 2014. Luigi Nono, Das atmende Klarsein. Text - Musik Struktur. Saarbrücken: PFAU Verlag.

33. Saint Girons Baldine. 2005. Pour une théorie de "l'ornance": les leçons de l'art mural. In Laroque D.; Saint Girons B. (Eds). 2005. Paysage et ornement. Paris: Verdier, p. 57-73.

34. Schoenberg Arnold. 2006. The Musical Idea and the Logic, Technique, and Art of its Presentation. trans. by Carpenter P.; Neff S. Bloomington: Indiana University Press.

35. Schoenberg Arnold. 2010. 1st ed, 1975. Style and Idea. Oakland: University Press of California.

36. Vieira de Carvalho Mário. 1999. Towards Dialectic Listening: Quotation and Montage in the Work of Luigi Nono. Contemporary Music Review, v. 18, n. 2, p. 37-85. 